\title{
Biochemical Markers of Lymphocyte Maturation
}

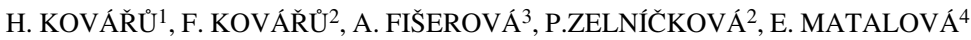 \\ ${ }^{1} 1^{\text {st }}$ Faculty of Medicine, Charles University, Prague, ${ }^{2}$ University of Veterinary and Pharmaceutical Sciences, \\ Brno, ${ }^{3}$ Institute of Microbiology, Academy of Sciences \\ of the Czech Republik, Prague ${ }^{4}$ Institute Animal Physiology and Genetics, \\ Academy of Sciences of the Czech Republic, Brno, Czech Republic
}

Received July 22, 2002

Accepted November 18, 2002

\section{Abstract}

Kovářů H., F. Kovářů, A. Fišerová, P. Zelníčková, E. Matalová: Biochemical Markers of Lymphocyte Maturation. Acta Vet Brno 2002, 71: 503-508.

We studied maturation-associated changes of cell membrane $\mathrm{Na}^{+}, \mathrm{K}^{+}$- and $\mathrm{Mg}^{2+}$-ATPase activities and gamma-glutamyltranspeptidase activity (GGT) during prenatal and postnatal development of lymphocytes in pig thymus and lymph nodes, i.e. primary or secondary lymphoid organs. Furthermore, we analyzed the developmental changes in expression of alpha subunits (Gs, $\mathrm{Gq} / 11$ ) of membrane heterotrimeric GTP-binding proteins.

We demonstrated marked developmental decrease of both $\mathrm{Na}^{+}, \mathrm{K}^{+}$- and $\mathrm{Mg}^{2+}$-ATPase activities in thymus and lymph node lymphocytes. On the other hand, we found elevated membrane gammaglutamyltranspeptidase (GGT) activity as a function of age in lymph node lymphocytes in contrast to declined GGT in thymus. These findings are probably associated with antibody formation related to antigenic pressure during postnatal development.

Finally, we assayed developmental changes of $\mathrm{G}$ alpha (s) and $\mathrm{G}$ alpha q/11 subunits in thymus and lymph nodes. There were ontogenetic specifities in expression of $\mathrm{G}$ alpha (s) or $\mathrm{G}$ alpha q/11 and appropriate effector enzyme systems generating of $2^{\text {nd }}$ messengers cAMP or $1,4,5 \mathrm{IP}_{3}$, respectively, in cell signal transduction.

The results of this study contribute to our understanding of the dynamic changes of both enzymes and $\mathrm{G}$ alpha subunit profiles at the level lymphocyte cell surface linked to maturation events in ontogenetic development.

Pig, ontogeny, thymus, lymph nodes, lymphocytes, ATPases, gamma-glutamyltranspeptidase, heterotrimeric GTP-binding protein, G-protein

It is generally accepted that $\mathrm{T}$ and $\mathrm{B}$ lymphocytes and their subpopulations are characterized by morphological and phenotypic markers, including surface antigens or receptors. Their cell surface enzyme equipment can be different as well. These enzymes belong to various groups, e.g. phosphatases, nucleotidases, kinases, peptidases and glycosidases with possible functions in cell activation, maturation, differentiation, molecules transducing cell signal and adhesive structures (Naquet and Pierres 1991; Benrezzak et al. 1999).

Adenosine triphosphate phosphohydrolases (ATPases), catalysing hydrolysis of ATP to ADP and inorganic phosphate, are ubiquitous transmembrane enzymes in higher eukaryotes, (Mas at et al. 1996; Anner and Volet 1999). When catalytic activity of ectoATPases is inhibited, e.g. $\mathrm{Mg}^{2+}, \mathrm{Ca}^{2+}$ - ATPase by irreversible antagonists, then T-, B- and NK cell effector functions are influenced, e.g. antigen-induced cytokine secretion and cytolytic activity, antibody formation and spontaneous proliferation (B arankie wicz et al. 1988; Dombrowski et al. 1998).

$\mathrm{Na}^{+}, \mathrm{K}^{+}$-ATPase is a fundamental enzyme system dependent on composition and properties of phospholipid microenvironment and it consists of alpha and beta subunit (Webb et al. 1995; Anner and Volet 1999). Various structural changes in enzyme

Address for correspondence:

Assoc. Prof. RNDr. Hana Kovárůu, DrSc

$1^{\text {st }}$ Faculty of Medicine

00 Prague 2
Phone: +420224965382

Phone: +420 224965382

Fax: +420224910577

http://www.vfu.cz/acta-vet/actavet.htm 
molecule, such a loss of beta-1 subunit, are associated with maturation states in $\mathrm{T}$ and B lymphocytes and subsets in (Mas at et al.1996).

Besides cell surface ATPases from lipid-dependent regulatory group, we focused our attention to gamma-glutamyltranspeptidase (GGT), an enzyme without lipid microenvironment influence. This enzyme catalyses glutamyl residue transfer from gammaglutamylpeptides and their derivatives to a cceptors. GGT plays a role in glutathione metabolism and transport of amino acids and small peptides across cell membrane (Lisý and Lodin 1977; Kovářů 1992; Lawrence et al. 2000). Higher GGT activity can be related to differentiation stages of normal and neoplastic cells. Immunoregulatory role of GGT and glutathione in vivo was studied using GGT knockout mice or GGT participation in effector T cells (Lawrence et al. 2000; Roozendaal et al. 2001).

The above-mentioned enzymes are a part of modulation of cell signal transduction. Important role in transmembrane cell signalling is played by membrane heterotrimetric GTP-binding proteins ( $G$ proteins). Heptahelical transmembrane receptors for external signal molecules (drugs, neurotransmitters, hormones, cytokines etc.) are coupled to $\mathrm{G}$ proteins, composed of, and chains that act as cell signal transducers and amplifiers modulating more effector systems and second messenger pathways (Malbon 1997). Functionally important $\mathrm{G}$ subunits differ in effects on effectors: Gs and Gi (stimulation and inhibition of adenylyl cyclase, etc.), Gq/11 (influence of phospholipase C) and Go (ion channel action), (Milligan 1988; Malbon 1997).

Molecular physiology mechanisms underlying B- and T-cell development are poorly understood as yet. Differential G protein expression in B- and T-cell development including $\mathrm{G}$ alpha s and $\mathrm{G}$ alpha q/11 were studied (Grant et al. 1997). Role of G protein-coupled receptor in T cell development is suggested, including development of T helper cell immune responses (Zabel et al. 1999). T lymphocyte activation with engagement of T cell receptorCD3 complex is modulated by heterotrimeric $G$ proteins, including $G$ alpha q/11 family (T soukas et al. 2000). Modulation in expression of main type $\mathrm{G}$ alpha subunits of natural killer lymphocytes was investigated (Kovářů et al. 2001).

We focused our attention on more detailed analyzes of spontaneous developmental changes of cell membrane $\mathrm{Na}^{+}, \mathrm{K}^{+}$- and $\mathrm{Mg}^{2+}$ - ATPase activities during prenatal and postnatal development of pig thymus and lymph nodes, primary and secondary lymphoid organs. Furthermore, we studied changes of gamma-glutamyltranspeptidase activity (GGT). We also analyzed the developmental levels of $\mathrm{G}$ alpha subunit $(\mathrm{Gs}, \mathrm{Gq} / 11)$ in pig thymus and lymph nodes. This study is expected to contribute to information about dynamic changes of both enzyme and $\mathrm{G}$ alpha subunit profiles at the level lymphocyte cell surface linked to maturation events.

\section{Materials and Methods}

Experimental animals

We used fetuses and piglets (Czech Large White; 8 for each age) of three litters. Optimal halothan-oxygen$\mathrm{N}_{2} \mathrm{O}$ anaesthesia was used during experimental hysterotomy and other experimental procedures (Kovářů et al. 1971; Kovář ů et al. this volume). Fetuses FD 90 and FD 110, which were used as newborn, were obtained by experimental hysterotomy. Piglets of this age (FD 110) are routinely used e.g. in gnotobiology as germ-free animals and their organ systems are fully functionally and morphologically developed. Postnatal piglets were reared under physiological conditions and fed maternal milk. Starting day 5 to day 30, ČOS-1 commercial feed mixture was provided. On day 30 (weaning), a stepwise change for C̆OS-2 commercial diet was performed and this diet was used until day 60. Experimental animal care was provided according to recommendation of FELASA and European Community directives.

Preparation of thymus or lymph node lymphocytes

Thymus or lymph node tissue fragments were dissociated in Potter-Elvehjem homogenizer in MEM medium, $10 \mathrm{mM}$ HEPES, pH 7.3, spleen lymphocyte were purified by elimination of erythrocytes by hypotonic lysis and cells of reticula by clumping in $\mathrm{Ca}^{2+}, \mathrm{Mg}^{2+}$ - free buffer. Cells were kept in $1 \%$ BSA containing MEM medium, 10 mM HEPES, pH 7.3 at $4{ }^{\circ} \mathrm{C}$ overnight (for other details, see Kovářů et al. 1997). 
Enzyme activities

ATPase activities were measured by spectrophotometric semimicromethod of released inorganic phosphate. Enzyme buffers were of various compositions in mM: $\mathrm{Na}^{+}, \mathrm{K}^{+}$- ATPase $-100 \mathrm{NaCl}, 10 \mathrm{KCl}, 3 \mathrm{MgCl}_{2}$, with 30 Tris-HCl, pH 7.3 +/- $0.3 \mathrm{mM}$ ouabain, $1 \mathrm{mM}$ ATP (Serva, synthetic), $\mathrm{Mg}^{2+}$ - ATPase activity was estimated as difference between total ATPase and ouabain sensitive $\mathrm{Na}^{+}, \mathrm{K}^{+}$- ATPase, For other details see preceding papers (Kovářů et al. 1997).

GGT activity

Enzyme activity was estimated by using gamma-glutamyl-p-nitroanilide as the donor of the gamma-glutamyl residue in presence glycylglycine as the acceptor (Lisý and Lodin 1977).

G alpha subunit estimation

$\mathrm{G}$ alpha changes in cholate membrane extracts were analyzed by ELISA technique with our rabbit antibodies against synthetic C-terminal dekapeptides of alpha chains of $\mathrm{Gs}$ and $\mathrm{Gq} / 11$ (Milligan 1988). No cross reaction between our anti $G$ alpha - antisera and initial peptides for immunization was detected. ELISA method of competitive inhibiton was performed, modified by us with use of Maxisorp microtitration plates (NUNC) for noncovalent peptide binding. Immunochemical staining alkaline phosphatase conjugated with goat antirabbit IgG and p-nitrophenylphosphate as substrate was used. Results were confirmed by Western immunoblotting. For other details see Kovářủ et al. 1998.

Statistical analysis

The data are expressed as mean values +/- S.D. The differences between experimental samples were evaluated by unpaired Student's $t$-test.

\section{Results and Discussion}

Spontaneous ontogenetic development of both ATPase activities, $\mathrm{Na}^{+}, \mathrm{K}^{+}-$and $\mathrm{Mg}^{2+}-$ ATPases, was characterized as an age-dependent decrease in thymus and lymph node lymphocytes (Tab. 1 and 2). In more detail, $\mathrm{Mg}^{2+}$ - ATPase activities were lower in thymus than in lymph nodes. This organ dependence of $\mathrm{Mg}^{2+}$ - ATPase activity is similar to the enzyme changes observed in other species, such as rabbit or mouse (Tandon et al. 1983; Hell et al. 1985; Kovářů 1992). We demonstrated age dependent changes in $\mathrm{Mg}^{2+}$ ATPase activities, i.e. lower mesenterial lymph node - and higher peripheral lymph node lymphocyte - enzyme activity $(p<0.01)$. These characteristics can reflect effects of both developmental and environmental factors on both lymph node systems. The data indicate a relationship of $\mathrm{Mg}^{2+}$ - ATPase activity in lymphoid organs and maturation events (Hell et al. 1985; Barankiewicz et al. 1988; Benrezzak et al. 1999). This enzyme participates

Table 1

Development of ATPase and GGT activities in thymus. s.a.- specific activity in nmol Pi/10\% $1 \mathrm{~h}$

\begin{tabular}{|c|c|c|c|}
\hline Age (days) & $\mathrm{Na}^{+} \mathrm{K}^{+}$-ATPase (s.a.) & $\mathrm{Mg}^{2+}$-ATPase (s.a.) & GGT (s.a.) \\
\hline 15 & $1.8 \pm 0.3$ & $17.0 \pm 1.2$ & $33.1 \pm 3.4$ \\
\hline 30 & $1.5 \pm 0.2$ & $15.1 \pm 1.5$ & $35.9 \pm 0.5$ \\
\hline 60 & $1.3 \pm 0.1$ & $8.9 \pm 0.6$ & $23.7 \pm 0.4$ \\
\hline 90 & $0.8 \pm 0.6$ & $15.5 \pm 0.1$ & $23.4 \pm 0.3$ \\
\hline
\end{tabular}

Table 2

Development of ATPase and GGT activities in lymph nodes. For other details see Table 1.

\begin{tabular}{|c|c|c|c|c|c|c|}
\hline \multirow{2}{*}{$\begin{array}{c}\text { Age } \\
\text { (days) }\end{array}$} & \multicolumn{3}{|c|}{ Mesenteric } & \multicolumn{3}{c|}{ Peripheral } \\
\cline { 2 - 7 } & $\mathrm{Na}^{+} \mathrm{K}^{+}$-ATPase (s.a.) & $\mathrm{Mg}^{2+}$-ATPase (s.a.) & GGT (s.a.) & $\mathrm{Na}^{+} \mathrm{K}^{+}$-ATPase (s.a.) & $\mathrm{Mg}^{2+}$-ATPase (s.a.) & GGT (s.a.) \\
\hline 15 & $11.8 \pm 1.5$ & $48.61 \pm 5.8$ & $24.2 \pm 3.0$ & $32.8 \pm 4.1$ & $105.8 \pm 9.1$ & $40.0 \pm 0.8$ \\
\hline 30 & $10.2 \pm 1.2$ & $35.18 \pm 2.8$ & $29.4 \pm 0.6$ & $16.9 \pm 1.5$ & $56.0 \pm 2.6$ & $40.7 \pm 1.6$ \\
\hline 60 & $6.8 \pm 1.2$ & $22.10 \pm 2.2$ & $42.9 \pm 4.5$ & $12.6 \pm 1.3$ & $52.9 \pm 3.0$ & $57.9 \pm 1.0$ \\
\hline 90 & n.d. & n.d. & $78.1 \pm 3.0$ & $10.7 \pm 1.0$ & $49.0 \pm 1.5$ & $91.5 \pm 3.4$ \\
\hline
\end{tabular}


in many lymphocyte effector mechanisms in all components of immunity, i.e. natural, cell and humoral immune responses (Dombrowski et al. 1998).

We observed a markedly lower $\mathrm{Na}^{+}, \mathrm{K}^{+}$- ATPase activity than that of $\mathrm{Mg}^{2+}$ - ATPase in both thymus and lymph node lymphocytes at all tested intervals. Prenatal and postnatal changes of $\mathrm{Na}^{+}, \mathrm{K}^{+}$- ATPase were characterized by a sharp decline to $20 \%$ and $32 \%$ in thymus and lymph nodes, respectively (Fig. 1). Furthermore, we studied the relationship between $\mathrm{Na}^{+}, \mathrm{K}^{+}$- ATPase, membrane lipid fluidity and lymphocyte maturation (Kovářu 1992). We demonstrated also participation of $\mathrm{Na}^{+}, \mathrm{K}^{+}$- ATPase activity in mitogen lectin induced lymphocyte activation from quiescent state related to DNA synthesis and proliferation (Kovářů H. et al. 2003, in press).

Gamma-glutamyltranspeptidase (GGT) activity increased markedly both as a function of age in lymph node lymphocytes and as compared to declined thymus lymphocyte enzyme activity (Tab. 1 and 2). Postnatal lymph node GGT activity was increased to 257\% (PD 90) compared to FD 80, whereas opposite changes were found in thymus, i.e. decrease to $51 \%$ on PD 90 (Fig. 2). The ratio of lymph node/thymus lymphocyte GGT on PD 60 and PD 90 was approximately 3 and 5 , respectively, and this range is to some extent similar to human B/T lymphocyte GGT ratio (Kovářů 1992; Lawrence et al. 2000). It is suggested that higher GGT activity in lymphocytes can indicate a relationship to synthesis of immunoglobulin and lymphokine secretion by these cells. We demonstrated that spontaneous developmental changes are probably consequence of B lymphocyte functional maturation with immunoglobulin synthesis as demonstrated by intrauterine immunization or postnatal immunization (Kovář̉ F 1992; Kovářủ F et al., this volume).
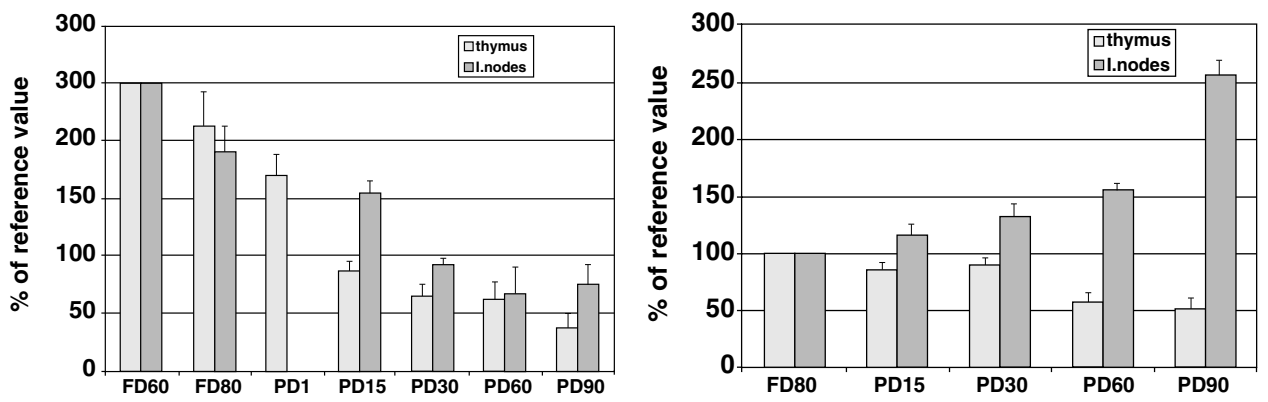

Fig. 1: Development of activity of $\mathrm{Na}^{+}, \mathrm{K}^{+}$- ATPase Fig. 2: Development of activity of GGT activity in activity in thymus and lymph nodes (\% of reference thymus and lymph nodes. For other details see Fig. 1. activity). Fetal days (FD) and postnatal days (PD), thymus (hatched columns), lymph nodes (dark columns)

G-proteins. In thymus, the developmental role of $\mathrm{G}$ alpha q/11 subunit expression can be important because of its high levels in prenatal period compared to levels of Galpha q/11 in lymph nodes elevated from fetal to neonatal life $(p<0.05)$ (Fig. $3 \mathrm{ab}$ ). Level of $\mathrm{G}$ alpha (s) subunit was markedly increased as function of age from fetal to postnatal intervals in both thymus and lymph nodes $(p<0.01)$. All data indicate the role of main subtypes of $\mathrm{G}$ proteins in cell signal transduction to intracellular responses via both effector systems adenylyl cyclase, and phospholipase $\mathrm{C}$ generating cAMP or 1,4,5 $\mathrm{IP}_{3}$ messenger.

The role of $\mathrm{G}$ protein coupled receptor in $\mathrm{T}$ cell development is suggested, including $\mathrm{G}$ alpha q family in B lymphocyte differentiation (Mapara et al. 1995; Zabel et al. 1999). Furthermore, $G$ proteins in transmembrane cell signalling during lymphocyte activation with engagement of $\mathrm{T}$ cell receptor-CD3 complex were modulated by heterotrimeric $\mathrm{G}$ proteins, including $\mathrm{G}$ alpha q/11 family (Ts oukas et al. 2000). cAMP dependent cellgrowth inhibition of T cell line, Jurkat cells was studied (Gouy et al. 1991). It is evident 

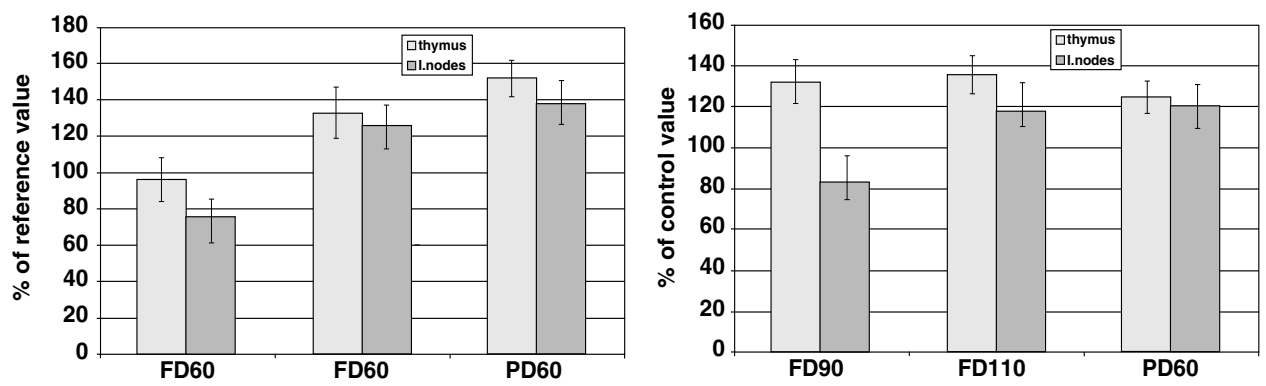

Fig. 3: Development of G alpha (s) (3a, left) a G alpha q/11 (3b, right) subunit levels in thymus (light columns) and lymph nodes (dark columns), G alpha q/11, G alpha (s) (\% of reference level on PD 90)

that $\mathrm{G}$ proteins regulate a diverse range of biological responses including growth, proliferation and differentiation.

In this paper, we studied membrane enzymes and $\mathrm{G}$ proteins as probable markers involved in lymphocyte maturation of both thymus or lymph nodes. Our results indicate that further elucidation of the role of membrane systems - GGT, ATPases and G proteins will provide a valid basis for understanding their role in lymphocyte effector functions.

\section{Biochemické znaky maturace lymfocytů}

Zaměřili jsme se na studium maturačních dějů buněčného povrchu a studovali jsme aktivity $\mathrm{Na}^{+}, \mathrm{K}^{+}$- a Mg ${ }^{2+}$ - ATPasy a gama-glutamyltranspeptidasy (GGT) lymfocytů během prenatálního a postnatálního vývoje prasečího thymu a lymfatických uzlin, tj. primárního a sekundárního lymfatického orgánu. Dále jsme analyzovali vývojové změny exprese alfa subjednotek (Gs, Gq/11) membránových heterotrimerních GTP-vazebných proteinů.

Prokázali jsme vývojově pokles aktivit $\mathrm{Na}^{+}, \mathrm{K}^{+}-\mathrm{a} \mathrm{Mg}{ }^{2+}$-ATPasy lymfocytů jak $\mathrm{v}$ thymu tak v mízních uzlinách. Na druhé straně jsme stanovili vzestup GGT aktivity v lymfocytech mízních uzlin na rozdíl od snížené aktivity enzymu. Tyto změny jsou patrně spojeny s tvorbou protilátek působením antigenního tlaku.

Dále jsme analyzovali změny vývojových profilů $G$ alfa (s) a G q/11 subjednotky. Zjistili jsme ontogenetické specifity v obou lymfatických orgánech v expresi obou subjednotek, které ukazují roli efektorových enzymových systémů a příslušných druhých poslů cAMP a 1,4,5 $\mathrm{IP}_{3} \mathrm{v}$ transdukci membránového signálu.

Tato studie přispívá $\mathrm{k}$ pochopení dynamických změn jak enzymů tak profilů $\mathrm{G}$ alfa subjednotek na povrchu lymfocytů spojených s maturačními ději.

\section{Acknowledgement}

Supported by grants GAâR 304/01/0850, Int. Sci. Program CEZ: J 16/98: 161700001 FVL VFU Brno and MŠMT 111100001.

\section{References}

ANNER, BM, VOLET, B 1999: Uptake of reconstituted Na, K-ATPase vesicles by isolated lymphocytes measured by FACS, confocal microscopy and spectrofluorometry. Cell Biochem Biophys 30: 437-454

BARANKIEWICZ, J, DOSCH, HM, COHEN, A 1988: Extracellular nucleotide catabolism in human B and T lymphocytes. The source of adenosine production. J Biol Chem 263: 7094- 7098

BENREZZAK, O, GRONDIN, G, SEVIGNY, J, GENDRON, FP, ROUSSEAU, E, D’ORLEANS-JUSTE, P, BEAUDOIN, AR 1999: Identification and immunolocalization of two isoforms of ATP-diphosphohydrolase (ATPDase) in the pig immune system. Arch Biochem Biophys 370: 314-322

DOMBROWSKI, KE, KE, Y, BREWER, KA, KAPP, JA 1998: Ecto-ATPase: An activation marker necessary for effector cell function. Immunol Rev 161: 111-118 
GOUY, H, CEFAI, D, CHRISTENSEN, SB, DEBRE, P, BISMUTH, G 1991: Cyclic AMP- and inositol phosphateindependent inhibition of $\mathrm{Ca}^{2+}$ Influx by cholera toxin in CD3 -stimulated Jurkat T cells. A study with a cholera toxin resistant cell variant and the $\mathrm{Ca}^{2+}$ endoplasmic reticulum- ATPase inhibitor thapsigargin. J Immunol 147: 757-766

GRANT, KR, HARNETT, W, MILLIGAN, G, HARNETT, MM 1997: Differential G-protein expression during B- and T-cell development. Immunology 90: 564-571

HEHL, EM, HENNIGHAUSEN, G, LANGE, P 1985: Ecto-ATPases in leukocytes and its modification by drugs. Allerg Immunol (Leipzig) 31: 17-23

KOVÁŘU F, STOŽICKY, V, KRUML, J, DLABAČ, V, DONÁT J, NOVOTNÁ, J 1971: Experimental surgery in the fetal period of mammals. Acta Vet Brno, Suppl. 3, 40: 1-68

KOVÁŘ́̊, F 1987: Immunological characterization of pig ontogenetic model. DrSc Thesis, MBÚ ČSAV, Praha, Vol I/II, 1-507 (In Czech)

KOVÁŘU, H, KOVÁŘU, F, HAŠKOVÁ, V 1997: Cell surface enzymes of brain cortex cells or lymphocytes during early allogeneic reaction. Physiol Res 46: 137-144

KOVÁŘU, H, KOVÁŘU, F, ŽIŽKOVSKY V, VELEK, J 1998: Developmental changes of trimeric GTP-binding proteins in porcine brain and immune system. Acta Vet Brno 67: 15-20

KOVÁŘU, H, FIŠEROVÁ, A, KOVÁŘU, F, POSPÍŠIL, M, LISÁ, V 2001: Modulation of heterotrimeric GTPbinding proteins in immune systém. Czech J Anim Sci 46: 62-67

LAWRENCE, BP, WILL, Y, REED, DJ, KERKVLIET, NI 2000: Gamma-glutamyltranspeptidase knockout mice as a model for understanding the consequences of diminished glutathione on $T$ cell dependent immune responses. Eur J Immunol 30: 1902-1910

LISY, V, LODIN, Z 1977: In vitro influencing of brain gamma-glutamyl transpeptidase by some amino acids. Coll Czechoslov, Chem Commun 42: 2967-2974

MALBON, CC 1997: Heterotrimeric G-proteins and development. Biochem Pharmacol 53: 1-4

MASAT, L, CASCALHO, M, WABL, M 1996: Loss of the beta 1 subunit pump during differentiation. Eur J Immunol 26: 2731-2735

MILLIGAN, G 1988: Techniques used in the identification and analysis of function of pertussis toxin-sensitive guanine nucleotide binding proteins. Biochem J 255: 1-13

NAQUET, P, PIERRES, M 1991: Cell surface enzymes and lymphocyte functions. Current Opinions Immunol 3: 326-329

ROOZENDAAL, R, VELLENGA E, de JONG, MA, TRAANBERG, KF, POSTMA, DS, de MONCHY, JG, KAUFFMAN, JHF 2001: Resistance of activated human Th2 cells to NO- induced apoptosis is mediated by gamma-glutamyltranspeptidase. Int Immunol 13: 519-528

TANDON, NN, DAVIDSON, LA, TITUS, ED 1983: Changes in Na,K-ATPase activity associated with stimulation of thymocytes by Concanavalin A. J Biol Chem 258: 9850-9855.

TSOUKAS, CD, STANNERS, J, CHING, KA 2000: Activation of heterotrimeric GTP-binding proteins upon TCR/CD3 engagement. Methods Mol Biol 134: 319-324

WEBB, GD, TAYLOR, EA, OH, VM, YEO, SB, NG, LL 1995: Effect of extracellular potassium concentration on the sodium-potassium pump rate in human lymphocytes. Clin Sci (Colch) 88: 695-700

ZABEL, BA, AGACE, WW, CAMPBELL, JJ, HEATH HM, PARENT, D, ROBERTS, AI, EBERT, EC, KASSAM, N, QUI, S, ZOVKO, M, LAROSA, GJ, YANG, LL, SOLER, D, BUTCHER, EC, PONATH, PD, PARKER, CM, ANDREW, DP 1999: Human G protein-coupled receptor GPR9-6/CC chemokine receptor 9 is selectively expressed on intestinal homing $\mathrm{T}$ lymphocytes, mucosal lymphocytes, and thymocytes and is required for thymus-expressed chemokine-mediated chemotaxis. J Exp Med 190: 1241-1256 